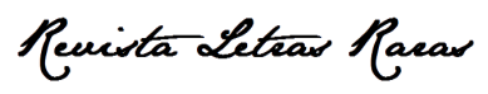

ISSN: 2317-2347 - v. 9, n. $3(2020)$

Todo o conteúdo da RLR está licenciado sob Creative Commons Atribuição 4.0 Internacional

\title{
Maurício e Minerva
}

\section{Roberto Remígio Florêncio*}

Graduado em Letras (UPE) e em Pedagogia (UNEB); Especialista em Língua Portuguesa (UNIVERSO) e em Literatura (MONTENEGRO); Mestrado em Educação e Cultura (Universidade do Estado da Bahia UNEB); Doutorando em Educação (Universidade Federal da Bahia - UFBA); Professor efetivo do Instituto Federal de Educação, Ciência e Tecnologia do Sertão Pernambucano.

\section{(iD https://orcid.org/0000-0003-3590-9022}

Recebido: 23 abr. 2020. Aprovado: 16 ago. 2020.

Como citar este conto:

FLORÊNCIO, Roberto Remígio. Maurício e Minerva. Revista Letras Raras, v. 9, n. 3, p. 286-288, ago. 2020.

Minerva agora é uma mulher quase louca.

Enquanto Maurício não vem, Minerva bebe e se enerva com qualquer ruído que faça algum dos seus cinco filhos. Pesam em sua cabeça dias de solidão e várias doses de cachaça. Quase quarenta anos. Uma vida de lutas, malsucedidas, que se diga. E certezas incertas... Maurício bebe na rua, mas sempre vem vomitar em casa. Maurício é o dono da casa. A mãe de Minerva, que mora no barraco em frente, não gosta quando a filha está bebendo, mas a velha, de mês em mês, também enche a cara, no dia em que recebe o dinheiro da aposentadoria. $E, 0$ que não dá para comprar o pão durante o mês, gasta de uma vez no botequim da esquina. Minerva pensa que a mãe se embriaga porque as pessoas lhe dão bebida. E assim vão vivendo em vão. Minerva acha que não. Ela pensa que é feliz e a vida na favela é uma beleza. Pobreza mesmo é pouca, o que se vê ao redor é a mais absoluta miséria. Lixo se espalha nos quintais, esgotos às portas das casas. Minerva varre o terreiro quando dá tempo de o sol secar um pouco do chão eternamente úmido e malcheiroso, escurecido pela sujeira do tempo. Minerva é uma mulher trabalhadeira, mas isso não adianta. Das mulheres da favela, é a que menos tem filho. Mas nada disso adianta. É tola. Sua inteligência infantil, seu raciocínio lento como um drama em

* betoremigio@yahoo.com.br 


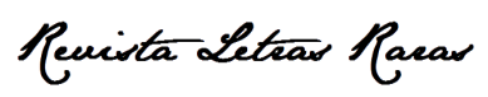

ISSN: 2317-2347 - v. 9, n. 3 (2020)

Todo o conteúdo da RLR está licenciado sob Creative Commons Atribuição 4.0 Internacional

câmara lenta do cinema francês. Seus meninos raquíticos estão sempre doentes ou famintos ou sumidos. As meninas maiores descem uma vez por semana para matar a fome na casa do pai também alcóolatra, mas morador do asfalto. Os três menores são filhos de outros favelados, sem paradeiros. Apenas o caçula, que chamam Bigui, é filho de Maurício. Ainda assim, ele tem dúvidas. Os meninos são uns pequenos capetinhas. Saem de manhã e voltam com fome à tardinha. Ainda bem que passam o dia todo fora de casa, senão seria o tempo inteiro de fome ali aos olhos desesperados da mãe. Os moleques tomam banho de lama, tomam banho ao sol e depois descascam o barro seco enegrecido. Tomam banho de chuva e estão sempre sujos. Sujos, fedidos e famintos. Quando as irmãs trazem algo comestível da casa do pai, eles avançam e comem até as cascas e embalagens. Não precisa estar limpo ou ser comestível... Minerva agora é uma bêbada. Transformou-se numa mãe desnaturada. Não pensa, não analisa, não pondera, grita impropérios, testa as crateras. Está do jeito que ela quer, sem as parcas pressões sociais que lhe amarram à condição humana. Só precisa de um homem para aplacar sua fúria. Precisa ser possuída, penetrada, consumida. Maurício deve estar também bêbado em algum ponto da cidade. Deve estar na cama de outra mulher. Deve estar gastando o dinheiro da quinzena. Na verdade, Maurício é esperto e ligeiro. Nesse momento, já fez tudo isso. Já transou com uma puta barata, já bebeu tudo o que pôde, já gastou todo o dinheiro. Minerva se esgota de cantar pela viela enlameada que lhe serve de acesso à casa. Os meninos choram na casa da avó, de medo e de fome - fosse-lhes dado algo para comer, calariam a boca e até se esqueceriam da pobre mãe. Minerva tenta chamar a atenção da favela para o espetáculo mais comum ali, tão reprisado por eles próprios. E, como de costume, ninguém olha. Só Julião, um negro de dois metros de altura por dois de largura, que para um minuto sua concentração na sinuca para observar a doida varrida que tenta impressionar. Ele pensa: é com essa que eu vou foder hoje. Ela reage em pensamento: pode vim, negão, pode vim... Maurício agora é um rosto na multidão. Apressado, cambaleante. Precisa chegar a algum lugar. Precisa ir. Não sabe exatamente para onde, para que lado caminhar já que não tem noção de espaço nem tempo se não tiver relação com o trem que o conduz todos os dias. Nunca aprendera a ler. 0 corpo dói, a cabeça gira. Mesmo assim, orgulha-se: a cachaça foi grande! Os carros passam raspando a guia, a cem por hora. Quando um de repente já não passa, não raspa, atropela o bêbado sem nome. Esmaga a sua perna. Mas, sem grito, nem dor, nem barulho. Maurício agora é um indigente num hospital da rede pública. Um precário hospital estadual que não tem médico de plantão nem material descartável. Minerva está mais calma. Tem sobre ela mais de cem quilos. 


\section{Peuista Letras Paras}

ISSN: 2317-2347 - v. 9, n. $3(2020)$

Todo o conteúdo da RLR está licenciado sob Creative Commons Atribuição 4.0 Internacional

O negro sua. Ela arfa de dor verdadeira e prazer falso. Fazem movimentos rápidos e barulhentos. As crianças dormem famintas no barraco em frente. Maurício geme de dor no hospital. Não aparece ninguém. Minerva geme debaixo do negro. Gemem alto. Gritam. Maurício esgota suas forças. Julião solta um urro, um arroto de cerveja choca, um peido. Levanta-se, veste a camisa, sobe o surrado jeans e vai embora. Minerva continua bêbada. Não gozou, não sentiu nada. Maurício chora, se arrepende, chama seu nome. Minerva! Minerva pensa que dorme. Sente-se pior, a casa roda. Tudo é uma roda, parece morta, uma roda vida. Chama desesperadamente. Maurício! Maurício desiste dos gritos, ele está sozinho, com frio e adormece de dor. Alguém the aplicou um sedativo barato e talvez vencido. Minerva chora e sente pena. Do marido, de si mesma. Minerva e Maurício. Maurício e Minerva estão na mesma solidão. 